\title{
Intersections
}

Canadian Journal of Music

Revue canadienne de musique

\section{"We Shall Be Better Canadians by Being Conscious Jews": Multiculturalism and the Construction of Canadian Identity in the Toronto Jewish Folk Choir}

\section{Benita Wolters-Fredlund}

Volume 25, numéro 1-2, 2005

Northern Perspectives on Music and Culture

URI : https://id.erudit.org/iderudit/1013311ar

DOI : https://doi.org/10.7202/1013311ar

Aller au sommaire du numéro

Éditeur(s)

Canadian University Music Society / Société de musique des universités canadiennes

ISSN

1911-0146 (imprimé)

1918-512X (numérique)

Découvrir la revue

Citer cet article

Wolters-Fredlund, B. (2005). "We Shall Be Better Canadians by Being Conscious Jews": Multiculturalism and the Construction of Canadian Identity in the Toronto Jewish Folk Choir. Intersections, 25(1-2), 187-201.

https://doi.org/10.7202/1013311ar
Résumé de l'article

À partir des notes de programme, cet article décrit l'évolution et la croissance de l'identité canadienne dans la chorale Toronto Jewish Folk Choir, pendant et après la Seconde Guerre mondiale. Durant cette période, la chorale a fait usage d'une rhétorique semblable à celle qu'on qualifierait aujourd'hui de multiculturalisme, afin de justifier leur place dans la culture canadienne. Les prétentions de la chorale à une identité canadienne sont comparées aux attitudes colonialistes et assimilatrices de l'époque envers le domaine culturel. L'exercice démontre, à travers les concerts et les discours, que les membres du chœur étaient en mesure de se construire une identité canadienne positive malgré leur situation de minorité ethnique étrangère au courant politique officiel.
Copyright @ Canadian University Music Society / Société de musique des universités canadiennes, 2005
Ce document est protégé par la loi sur le droit d'auteur. L'utilisation des services d'Érudit (y compris la reproduction) est assujettie à sa politique d'utilisation que vous pouvez consulter en ligne. 


\section{"We Shall Be Better Canadians by Being Conscious Jews": Multiculturalism and the Construction of Canadian Identity in the Toronto Jewish FolK CHOIR $^{1}$}

\section{Benita Wolters-Fredlund}

One of the most compelling aspects of the history of the Toronto Jewish Folk Choir is the way in which the choir's musical activity was related, in a very conscious and deliberate way, to their identity and mission as a choir. This is especially the case since their repertoire choices were unusually broad; although their repertoire during the 20s and 30s consisted only of Yiddish folksongs and cantatas, during the 40s and 50s they started singing folksongs of other lands and people, classical works by the likes of Bach, Beethoven, Handel and Schubert, and contemporary pieces, often as premieres, by composers like Shostakovich, Britten, and Weinzweig. Furthermore, the choir's identity was multi-faceted, with Jewish, politically progressive, working-class and Canadian elements (see below), making the connections between their repertoire and identity fascinatingly complex as well as instructive.

Thankfully, many of the choir's concert programmes from their early history are extant (they are housed in the music division of Library and Archives Canada ${ }^{2}$ ). The choir's programmes include a rich and large body of texts, in Yiddish and English, in which connections between their musical activity and their identity are made explicit. These texts, which come in the form of greetings, notes on repertoire, and essays, played an important role in the life of the choir. Indeed, if one accepts that identities are not inherent, fixed entities, but, as Stuart Hall has described them, "narrativization(s) of the self," (Hall 1996, 4) the discourse within these texts can be understood as a key site at which the choir's identity and connections between their identity and musical activity were constituted and shaped. ${ }^{3}$ Accordingly, along with interviews with former choir members, these programme texts are the foun-

1 This article stems from the author's doctoral research at the University of Toronto.

2 The Toronto Jewish Folk Choir fonds (MUS 43) at Library and Archives Canada was acquired beginning in 1974 and includes material covering the years 1923-76. It contains $30 \mathrm{~cm}$ of textual records (including programmes, press clippings, choir bulletins, and administrative records), 144 photographs, an audio tape reel and a soundless film reel.

3 The important role of discourse in shaping musical activity has been dealt with at length in musicological scholarship in the last 15 years, which space does not permit me to review here. These trends are summarized by Lawrence Kramer, "music does important cultural work by being spoken of, and would not be what we call 'music' otherwise" $(2003,124)$. 
dation upon which my study of the choir's identity is based. ${ }^{4}$ Because the choir's programmes include this wealth of discourse in which connections between music and identity are made explicit, their history is a unique source for understanding the dynamics of identity and music as they work out in musical subcultures.

The identity of the Toronto Jewish Folk Choir was complex and involved overlapping facets of identity relating to ethnicity, class, worldview and nationality, and can be roughly summarized as Jewish, working-class, politically progressive and Canadian. ${ }^{5}$ Each of these facets (and thus the choir's identity as a whole) was dynamic, changing in both subtle and dramatic ways throughout their history. These changes are most obvious when comparing the choir's early years, 1925-39, when the choir was made up of young radical Jewish immigrant workers involved in the labour movement, to their war and post-war years, 1939-59, when they were conducted by Viennese-born conductor Emil Gartner and when historical circumstances encouraged them to address a broader array of political issues. But the facet which underwent the most dramatic change during the Gartner period was the choir's sense of Canadian identity, which developed largely after 1939 and was expressed and negotiated using rhetoric similar to what we would now call multiculturalism-and it is this facet of identity which is the focus of this article. As I shall describe, the choir's ideas about the relationship of culture, ethnicity and nationalism were unique for the period, and their multicultural rhetoric became a powerful strategy for claiming legitimacy and acceptance.

\section{EARLY HistoRY, 1925-39}

In order to describe the changes in national identity which occurred during the Gartner period, it will be helpful to briefly outline the choir's early history and explain its place in Canadian society during the pre-war years. In the late nineteenth and early twentieth centuries, thousands of Jews emigrated from Eastern Europe to Toronto to escape racial oppression and poverty. Although the levels of poverty and anti-Semitism were not as severe as they had been in their homelands, Canada was not the "Golden Land" for which they had hoped. Many of these working-class Jews could only find employment in the so-called needle trades, where they were frustrated by low wages, and harsh, unsanitary working conditions (Frager 1992,16). Many became leaders in an emerging socialist-oriented labour movement with various religious, secular, communist, Bundist, Zionist and other factions. Alongside the various Jewish-led union halls associated with this movement were left-wing Jewish fraternal organizations-mutual benefit societies which offered members death benefits, sick benefits, a cemetery, a credit union, Jewish children's

\footnotetext{
4 For a more detailed discussion of the theoretical approach used in the study of the folk choir, see the author's doctoral dissertation (Wolters-Fredlund 2005).

5 These various layers of identity are given more thorough treatment in the author's dissertation (cited above), and are also outlined in Wolters-Fredlund (2002).
} 
schools, and a range of cultural programmes. They were not unions as such, but their membership was left-wing and working class, and they supported labour actions.

The folk choir was associated with one such left-wing Jewish fraternal organization called the Labour League, which was established in 1926 and made up of young, activistic and radical Jewish workers. It was fervently secular, communist-oriented and pro-Soviet, although it had no official ties to the Communist Party. ${ }^{6}$ The choir, known originally as the Freiheit Gezang Farein (Freedom Singing Society) was only one of the Labour League's cultural programmes, which also included child and adult mandolin orchestras, a drama group, sports teams, English classes, and lectures on socialist topics. In 1945 the Labour League joined a number of similar organizations around Canada to form a national organization known as the United Jewish Peoples Order (UJPO), which continued to support the choir throughout the Gartner period and supports it to this day. Although the membership of the choir aged and began to move out of the working class during the $40 \mathrm{~s}$ and $50 \mathrm{~s}$, the choir continued to identify with their left-wing, working class and activist origins.

During these early years of their history (1925-39), the choir lived very much outside the Canadian mainstream, not only because its membership and audience were made up of an ethnic minority of the working classes, but also because the revolutionary politics of the group were decidedly anti-establishment in nature. Furthermore, communist politics were not at all popular in Canada during the 1930s, and were treated with suspicion and hostility. This was so much the case that the Labour League and the choir specifically were harassed by the police in early years. As long-time member Morris Biderman explains in his autobiography,

Left-wing organizations had it rough in those years at the beginning of the 1930s. It was the period of the struggle for free speech in Toronto ... Communists and organizations suspected of being under their influence could not rent a hall for a meeting. The choir could not rent a hall for a concert anywhere in the city of Toronto.

Once we rented a hall on Spadina and the choir was not allowed in on the day of the concert. In protest we sang outside on the street. The choir did give one concert at the Finnish Hall on Broadview above Danforth, which was then outside the city limits where Draper [famously anti-communist chief of police] and his police had no jurisdiction. To get into the hall was a challenge though. Police surrounded the building to scare people away. But the people who came from the streets of Ward Four-from Brunswick, Bellevue, Major, Robert and the others-brought strong convictions with

6 The political affiliations of the choir and its sponsoring organization (Labour League/United Jewish People's Order) are discussed by Shek (1997) and Biderman (2000). While both agree that it was never officially a Communist organization, they disagree as to the extent to which the Communist Party exercised influence over their organization. 
them and were not prepared to turn around and go home. They passed the police and entered the hall. The concert was a success. (Biderman 2000, 33-34)

The fact that they managed to forge on despite such obstacles was a point of pride celebrated by the choir, highlighted in their stirring slogan used throughout the years "With song to the struggle, Through struggle to victory." That they needed to struggle against the status quo to change the world also fit with their revolutionary politics, and their victory over various obstacles is celebrated in an essay on the choir's history, also by Biderman, written in 1936:

Who doesn't remember the times when it was impossible to conduct a meeting undisturbed, when every worker who came into this local was persecuted and threatened with deportation? Who doesn't recall the time when the Freiheit Gezang Farein had to sing in the street and fight in the street for the right to bring revolutionary songs to the Jewish worker in Toronto? Who doesn't remember the time when the mandolin orchestra had to hold its rehearsals in private homes, in garrets and in secret places? But its spirit was never broken, its resolve never weakened and the difficulties were eventually eliminated. The Jewish Workers Centre grew up and was tempered in struggle. One can truly say that the Culture Centre and its groups went with song into struggle and through struggle, they'll go to victory (Biderman's italics) (Library and Archives Canada, MUS 43, Box 1, (hereafter LAC 43/1), Concert Programme, "Der Groyser Yubiley fun dem Toronter Ydishn Arbeter Kultur Tsenter" [The Great Jubilee of the Toronto Jewish Worker Cultural Centre], M.B. [Morris Biderman], 9 May 1936, trans. Benita Wolters-Fredlund and Gloria Brumer).

Although programme texts from the early period are few, those that are extant make no reference whatever to the choir's Canadian context. The language of the programmes and repertoire is primarily Yiddish (although in the late 1930s English transliterations were given of the titles of pieces performed), and the anthem sung to begin concerts was not "God Save the King" but the left-wing anthem "Internationale." Instead, far more attention is given to the Soviet Union. A large percentage of the works performed in the early years are about Soviet policies (e.g. the cantatas Biro-Bidjan [Birobidzhan] and Kein Eintziken Shpan [Not a Single Step], which deal with the Soviet Jewish Autonomous Region established by Stalin and the sovereignty of the Soviet Union, respectively), are stories set in Russia (e.g. A Bunt Mit a Statchke [A Plot and a Strike] about a labour strike in small Russian town), and/or are written by Soviet writers such as Peretz Markish and Itzik Feffer. In at least one of the Yiddish folksongs the choir sang, the lyrics of which appeared on the back of the concert programme in Yiddish, Stalin himself is mentioned (LAC 43/3 Concert Programme, lyrics to "Memleket," 15 November [1936]). 


\section{Emerging Canadian Identity in the War and Post-War YEARS, 1939-59}

After the outbreak of war in 1939, the choir transferred their political energies from working for revolution to fighting fascism, and advocating world peace and human rights. Especially after Russia was attacked by Germany and became Canada's ally in World War II, the choir began to enthusiastically support the Canadian war effort which overlapped with their own anti-fascist, anti-Nazi and pro-Soviet beliefs. In fact, a number of choir members joined the Canadian armed forces. Programme texts after 1939, the year in which new conductor Emil Gartner was hired, frame the choir's activities within a Canadian context and describe the choir as having a Canadian identity. This was likely also related to the more general surge in Canadian patriotism and nationalism that occurred during and after the war-a period often referred to by historians as Canada's "coming of age." Cultural activity increased dramatically during the war as the country's artists began to frame their work as part of the war effort. As Sir Ernest MacMillan put it, "Music, literature and other arts [are] more than a mere means of escape for tired workers, [they are] symbols of the very things our brothers-in-arms are fighting for" (Tippet $1990,158-59)$. For the first time cultural activity was explicitly connected to nationalism in the public mind, and many producers of culture began to think of their cultural activities as distinctly Canadian.

It was during the war years that the choir's name was changed from Yiddish to English, concerts began to open with the singing of "God Save the King," and programmes, now mostly in English, began to include pro-war slogans and advertisements for buying war bonds. In the Yiddish section of a 1943 concert programme called Death to the Enemy, one page features the pictures of leaders of the allies-Mackenzie King (surrounded by Union Jack flags), Roosevelt, Chiang Kai-Shek, and Churchill and Stalin smiling at one another-with the Yiddish phrase "Mit Fareynikte Koykhes Farois Tsum Zig!" ("With united strength forward to victory!") above the images and "Back the Attack!" (see Figure 1 below) (LAC 43/1, Concert Programme, 21 May 1943). The same programme includes greetings from left-wing organizations that make a clear connection between Canada's war effort and leftist politics. The Canadian Tribune (a labour paper) greeted the choir with a quote from Soviet composer Dmitry Shostakovich: "Let music of our victory over common enemy sing out soon," while the Dominion and Ontario Communist-Labour Total War Committee explains how the choir's efforts can be understood as part of Canada's war effort:

Your organization has played and is playing an important and necessary role in raising the morale and fighting determination of the civilian population.

It has been said that words are bullets-and so is song-expressing as it does, in mighty voices, the hopes and aspirations of humanity in its fight for a better world. Not without reason did Baldur von Shirach, Hitler 


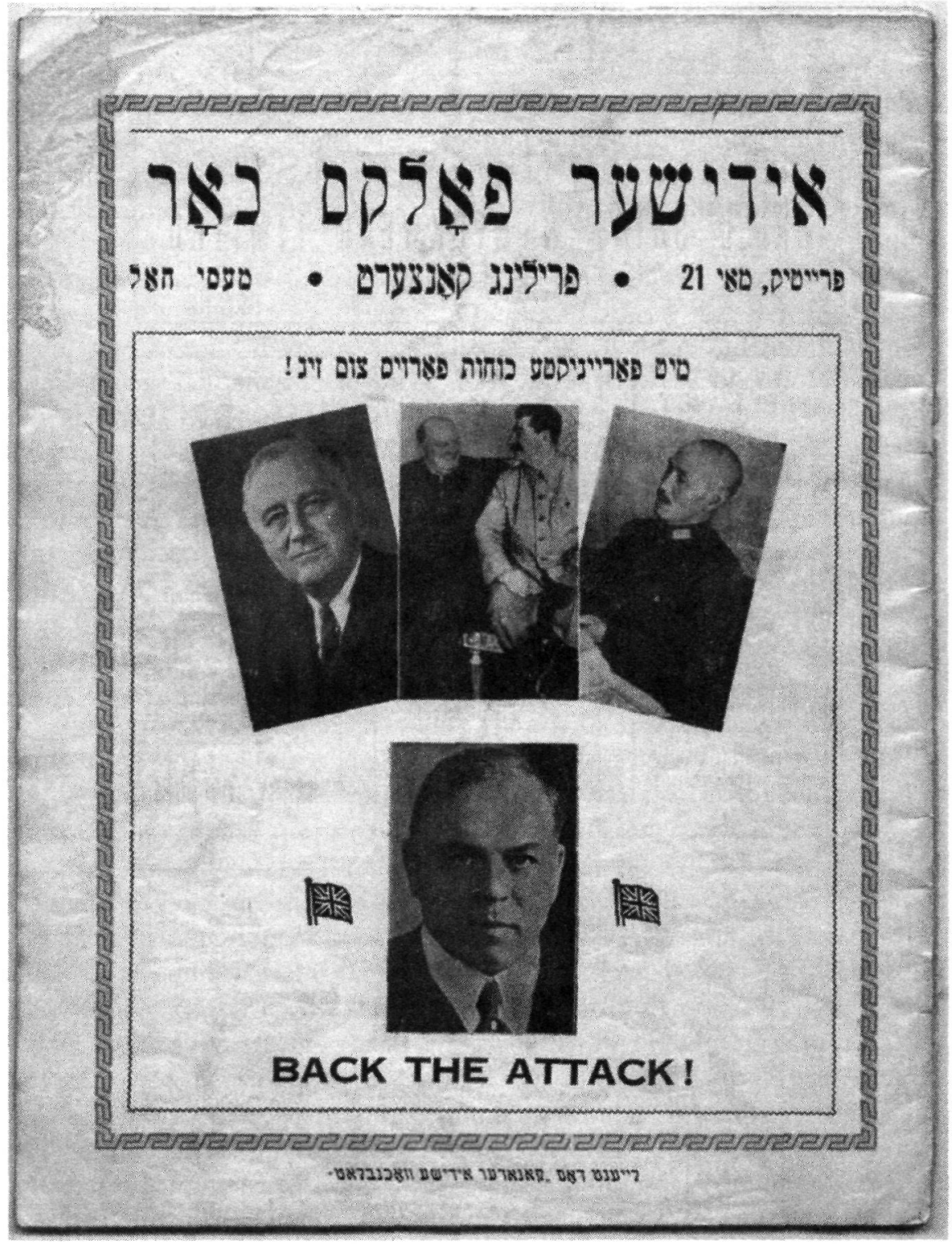

Figure 1. Images from a Concert Programme of the Toronto Jewish Folk Choir, 21 May 1943. Yiddish at top: "Jewish Folk Choir, Friday, May 21, Spring Concert, Massey Hall" Library and Archives Canada/e002344178.

youth leader, state: "When I hear the word culture I reach for my gun." For fascism not only smashes labour and its organizations, enslaves whole peoples and nations-it also must obliterate its culture of which song and music are such an essential part. Dumb slaves is what they want, not songs of the past, present and future, which represent the cultural advance in the forward march of the peoples everywhere. 
The Jewish Folk Choir, with its song of the people, is therefore making a useful contribution to the war effort of the nation, and to the enrichment of its culture. Yes! Songs are also bullets-explosive, dynamic words in music, which in our day can stimulate the overwhelming desire of the people to smash fascism and wipe it off the face of the earth.

So sing as you fight and fight as you sing! (LAC 43/1, Concert Programme, Greeting from the Dominion and Ontario Communist-Labour Total War Committee, 21 May 1943)

Even after the war had ended, the choir continued to affirm a Canadian identity, frequently referring to themselves as a Canadian cultural institution, and emphasizing the fact that the majority of their members were now Canadian-born: "With a very small exception, the Jewish Folk Choir is now made up of Canadian-born men and women, boys and girls, whose parents come from many different nationalities" (Concert Programme, "The Role of The Canadian Artist," Max Burstyn, 3 June 1950, Jewish Folk Choir Fonds 43/2, Library and Archives Canada). Programme texts from the post-war era also show that the choir participated in the flood of public dialogue occurring during that period concerning what Canadian culture was about and what models it should follow. Canada's participation in the war effort had caused Canadians to wonder what exactly this nation was that people were fighting for overseas. In what ways was Canada different from its colonial parents, England and France, and how did she differ from her sometimes-overwhelming neighbour, the United States? This general public dialogue was further fuelled when the government introduced a series of studies on various aspects of Canadian culture and identity. The broadest and most famous of these studies was the 1949 Royal Commission on National Development in the Arts, Letters and Sciences, also known as the Massey Commission, and this was followed by the Fowler Commission in 1955 on radio and television broadcasting, the O'Leary Commission in 1961 on magazine publication, and finally the Commission on Bilingualism and Biculturalism in 1963. As Eva Mackey and other scholars have pointed out, while each of these studies addressed different aspects of Canadian life, "all of them assumed that cultural development was essential for national identity" and were part of a "broader project to develop, articulate and promote national identity and culture" $(2002,54)$. In fact, culture and identity were discussed and negotiated to a much greater extent than ever before in Canada.

It is not surprising then to find that in this atmosphere of Canadian nationalism and discussions about culture and national identity we should find essays in the choir's programmes dealing with culture in general, Canadian culture, the choir's place in Canada, and the choir's Canadian identity. Interestingly enough, in 1947, twenty-four years before multiculturalism became official cultural policy in Canada, Emil Gartner advocates a multicultural approach to Canadian culture. In an essay that appeared in a concert 
programme entitled "Our Life, Our Art," Gartner argues that the best way for a Jew to enhance Canadian culture is to be Jewish:

The culture of a people could be best described as the sum total of all its achievements ... No, we Jews need not fear of being lesser Canadians by being better Jews; on the contrary, we shall be better Canadians by being conscious Jews. To those who doubt, let it be said that the coming of a culture, distinctly Canadian, will be moulded out of the cultural contributions of most, if not all peoples who, in their entirety are called: The Canadian People. There is nothing in our Jewish heritage that is contrary to a Canadian way of living. On the other hand, we may contribute to Canadian culture something priceless and absolutely irreplaceable: originality of creation, a beautiful colour in the rainbow of the world's cultural beauties. How could we in a better way show our love for Canada? ...

As Canadians we shall be able to sing the great song of Canada that is yet to be written, and we shall have contributed to it, we may hope, a phrase or two. (Concert Programme, "Our Life, Our Art!," Emil Gartner, 25 March 1947, Jewish Folk Choir Fonds 43/2, Library and Archives Canada)

Later texts support the basic thrust of Gartner's argument, such as the assertion in one 1955 programme that "It is our belief that every ethnic group can and should participate in the crystallization of a distinct Canadian culture" (Concert Programme, "Greetings," Executive Board, 14 May 1955, Jewish Folk Choir Fonds 43/3, Library and Archives Canada).

Although Gartner does not use the term multiculturalism, the idea that Canadian culture would emerge as a hybrid of its many cultures is startlingly similar to the official policy of multiculturalism adopted by the Canadian government in $1971 .^{7}$ The policy states: "We believe that cultural pluralism is the very essence of Canadian identity. Every ethnic group has the right to preserve and develop its own culture and values within the Canadian context" (Schafer 1998, 28). The document later elaborates, saying "[The various cultures and ethnic groups in Canada] will be encouraged to share their cultural expression and values with other Canadians and so contribute to a richer life for us all."

This multicultural framework which Gartner endorses allowed the choir to maintain Jewish and Canadian aspects of their identity simultaneously and

7 As the articles in Adelman and Simpson's Multiculturalism, Jews and Identities in Canada (1996) demonstrate, since Gartner's time Canadian Jews and Jewish organizations have tended to endorse and even advocate multicultural policies. Irving Abella, for example, states in his forward to the book, "Multiculturalism is a wonderful policy. And I say that as a Canadian and as a Jew and, of course, as president of the Canadian Jewish Congress" (viii). He later elaborates why he considers multiculturalism a good policy for Canadian Jews: "Where everyone is a hyphenated Canadian, Jews do not stand out from others when they include their Jewish as well as their Canadian identity" (xiii). It should be noted, however, that multicultural policies have come under increased criticism in recent years by Canadians of other ethnic backgrounds. See for example Himani Bannerij's The Dark Side of the Nation: Essays on Multiculturalism, Nationalism and Gender (2000) and Neil Bissoondath's Selling Illusions: The Cult of Multiculturalism in Canada (2002). 
even see the expression of Jewish culture as a patriotic act. The choir's Jewish and Canadian identities were linked, since expressing Jewish culture, and specifically performing Jewish works, was understood as an important contribution to the multicultural fabric of Canada's artistic and cultural life. This linking of Canadian and Jewish identities is often mentioned in milestone celebrations for the choir. In the year of the twentieth anniversary journalist and friend of the choir Joshua Gershman argues:

Twenty years of existence of the Jewish Folk Choir is a celebration for the whole of Jewish Canada. Moreover, it is the celebration of all of Canada. We are proud that we are making such an important cultural contribution to our country; the choir, like the whole of Jewish cultural life in Canada, is inseparable from the cultural life of the multilingual peoples of Canada. (LAC 43/1, Concert Programme, "A Virkzamer Kultur-Faktor Oyf Der Ydisher Gas" [An Important Cultural Factor of the Jewish Street], Joshua Gershman, 24 February 1944, trans. Gloria Brumer)

Five years later chorister John Stewart echoes these sentiments: "The Jewish people of Canada have immeasurably enriched Canadian culture through the Jewish Folk choir over its 25 years of singing ... It is a Jewish choir and a Canadian choir" (Concert Programme, "The Source of Its Strength," John Stewart, 3 June 1950, Jewish Folk Choir Fonds 43/2, Library and Archives Canada).

Gartner's multicultural vision for Canadian society should also be understood in the context of the choir's politically progressive orientation. An important aspect of the choir's repertoire choices was the practice of singing songs of many lands-in addition to singing Yiddish folksongs and other Jewish traditional repertoire, the choir sang music of the African-Americans, Australian Aboriginals, Maritime and French-Canadians, Chinese, English, French, Indonesians, Italians, Romanians, Russians, Scottish, Spanish and Ukrainians. Programme texts describe this diversity in their repertoire as a way to express and support the concept of the "brotherhood of mankind," or "kinship of humanity." Given the importance that the choir placed on this concept, it seems likely that a multicultural Canadian national identity would be similarly viewed as an appropriate expression of human equality and fraternity within one nation. They even argued that multiculturalism and, consequently, the "brotherhood of mankind" could also be observed in the membership of the choir itself, which began to include a minority of non-Jews during this period. As one chorister boasts, "In 1950, the choir includes not only Jews, but Scots, Irish, English, Negro and Japanese-all Canadians! This brotherhood within the choir itself is reflected in its singing and in its militant stand for unity of all peoples and world peace" (Concert Programme, "Twenty Five Years of Cultural Growth," Murray Tate, 3 June 1950, Jewish Folk Choir Fonds 43/2, Library and Archives Canada). Likewise, one programme from the 1950s of a sister group to the choir, the Canadian Folk Singers and Dancers 
Ensemble (another smaller UJPO cultural group directed by Fagel Gartner), describes their programming, which also brought together folk music from a wide variety of cultural traditions, as "truly Canadian cultural entertainment (emphasis mine)," and explains that in singing this diversity of repertoire the group hopes to "[make] a contribution towards the building of a genuine Canadian culture in this lovely land of ours and in a world of peace and brotherhood among men" (LAC 43/4, Advertisement for upcoming tour, Canadian Folk Singers and Dancers Ensemble, n.d. [1950s]).

One final aspect of the choir's growing Canadian identity during this period is their programming of Canadian repertoire. This repertoire, in addition to the Jewish repertoire and multicultural repertoire they performed, was part of their mission to support Canadian musical culture. Canadian folksongs especially were regularly included in concerts-besides Yiddish folksongs and African-American spirituals the most commonly programmed kind of folksong. On one occasion an extended essay on the history of Canadian folksong by Ruth Rubin also appears in programme notes emphasizing the multicultural fabric of Canada's music: "People from more than thirty nationalities settled in Canada. ... Along with their handicrafts and their skills, they brought their musical traditions" (Concert Programme, "Folk Songs of the French-Canadian People," Ruth Rubin, 3 June 1950, Jewish Folk Choir Fonds 43/2, Library and Archives Canada).

The choir programmed Canadian contemporary works during the Gartner period, commissioning and premiering works by John Weinzweig ("To the Lands Over Yonder"), Louis Applebaum (Newfoundland Songs-A Suite for Chorus), Robert Spurgel (All Thy Sons), and various orchestrations from Barbara Pentland. The choir's concert programmes also often included essays by Canadian composers, many of which discuss the difficulties associated with being a modern composer in the conservative Canadian climate of the period. Some examples include John Weinzweig's "Composer Meets Box Office" and "For Rent: One Ivory Tower," Barbara Pentland's "Wanted-an Audience," and her famous inflammatory essay, "Canadian Music" (first printed in the Northern Review), in which she claims that her generation is the first "real" generation of Canadian composers (Concert Programme, 25 March 1947; idem, 3 June 1950, Jewish Folk Choir Fonds 43/2, Library and Archives Canada).

The support that the choir gave to Canadian composers can be attributed in large part to Emil Gartner, who was himself friends with many of the Toronto composers he commissioned and was a champion of contemporary music, written by Canadians and non-Canadians alike. He was an advocate of the importance of modern music not only by commissioning and performing new works, but also by initiating a symposium series called "The Toronto Jewish Folk Choir Concert-Forum," the purpose of which was to discuss issues in contemporary music with Canadian composers, and listen to contemporary works. The first of this series took place in October of 1949 and 
included works by John Weinzweig and Murray Adaskin. Minutes of the choir executive committee record that Gartner also encouraged the choir to attend concerts of the newly formed Canadian League of Composers (CLC), even rescheduling a rehearsal so that members could attend one of the CLC's first concerts in Massey Hall with the Toronto Symphony Orchestra (Minutes of the Choir Executive, 18 March 1952, Jewish Folk Choir Fonds 43/4, Library and Archives Canada). Gartner's whole-hearted support of contemporary composers in general and Canadian composers in particular is especially interesting because this attitude was quite unique for the postwar period. Although a rise in nationalism and various national dialogues about Canadian culture had prompted some to support Canadian composers, by far the prevailing public attitude towards them during this period was apathy. Canadian composers, especially younger composers associated with more modern styles, were struggling for work and recognition during this period, when the more established Canadian ensembles, including the Toronto Symphony Orchestra and the Toronto Mendelssohn Choir, performed almost exclusively the high-brow "masterworks" of the European tradition and famously ignored modern trends.

\section{The Choir's Canadian Identity in the Context of Post-war CANADA}

The choir's programme texts and repertoire choices from this period make it clear that they embraced a patriotic Canadian identity during the war and post-war years, but there is reason to believe that they would have been seen by the Canadian mainstream as outsiders far more than as Canadians during this period. One might be tempted to see Emil Gartner's description of Canadian culture as a "rainbow of the world's cultural beauties" as proof that cultural pluralism already existed long before the policy of multiculturalism adopted by the Canadian government in 1971, but this perspective quickly becomes problematic when one considers some of the notorious examples of Canadian discrimination against minorities during this period-Canada's refusal to accept Jewish immigrants before and during World War II, other racist immigration policies of the period, the internment of Japanese, German and Italian Canadians during the war, and the post-war residential school programme for the children from Canada's indigenous communities being only a few of many examples. ${ }^{8}$

In fact, ethnicity and culture were conceived of in strictly colonial terms in the first half of the twentieth century in Canada, and citizens were expected to assimilate into either a British or French culture. As Eva Mackey has pointed out, a telling example of this attitude in federal immigration policy

8 See discussions of these various racist policies in Irving Abella and Harold Troper's None is Too Many: Canada and the Jews of Europe 1933-1948 (2000), Eva Mackey's The House of Difference: Cultural Politics and National Identity in Canada (2002), and Franca Iocovetta, et al., A Nation of Immigrants: Women, Workers, and Communities in Canadian History, 1840s-1960s (1998). 
can be seen in a pamphlet from the early 40 s that rates the desirability of new Canadians in terms of their ability to assimilate, or "Canadianize." It assures the reader, for example, that "Scandinavians, of all 'the racial groups' attracted to Canada in the last fifty years ... have 'presented the fewest problems in regard to assimilation" but that the Doukhobors "have been the most indigestible of any racial group admitted to Canada" (Mackey 2002, 51). The pamphlet continues in this vein, later asserting that although "the Hebrew Canadians have not intermarried much with those of the Aryan races, they are good citizens." Tellingly, when the government set out to study Canadian culture in the 1960s, the study was called the Royal Commission on Bilingualism and Biculturalism, with the assumption that Canada's culture was basically made up of French and English elements. As Maria Tippet has described, even during the postwar period, cultural institutions made up of ethnic minorities were seen as "islands unto themselves" considered to exist largely for the benefit of the communities out of which they arose, and not relevant to mainstream audiences (Tippet 1990, 29).

It is difficult to know exactly how the choir, specifically, was viewed during the Gartner years by Canada's dominant or mainstream culture. The choir expanded during the 40 s and 50 s to include over one hundred members and it gave multiple concerts a season in Massey Hall (one of Toronto's larger concert venues of the time), which were consistently sold out. They also invited renowned musicians such as Igor Gorin (1942), Alexander Kipnis (1946), Lois Marshal (1948), Jan Peerce (1949), Regina Resnik (1945, 1950), Jennie Tourel (1950), Paul Robeson (1946, 1947, 1948, 1949), to participate in their concerts, and collaborated with the Toronto Symphony Orchestra (1947). For a group from an ethnic minority, they had unusually high visibility in the Toronto community during these heyday years, and their collaborations with renowned operatic singers and especially with left-wing activist and singer Paul Robeson drew audiences from both the Jewish and non-Jewish community in Toronto. It certainly is the case that the choir began to receive much more press in mainstream newspapers after Gartner's arrival, much of it positive. But despite the choir's achievements during the 40s and 50 s, in an essay on choral music in Canada written in 1955, Sir Ernest MacMillan mentions the folk choir only briefly under the heading "special national groups" rather than under the standard "mixed choir" category $(1955,90)$. Similarly, MacMillan is quoted in one of the choir's brochures as saying "I am sure the choir must be a very valuable asset to the Jewish community (emphasis mine)" (Advertisement for upcoming concert, 10 May 1946, Jewish Folk Choir Fonds 43/1, Library and Archives Canada). These statements certainly seem to indicate that the choir continued to be seen as an organization outside the mainstream.

In this context, a period in Canada's history where colonial and assimilationist attitudes towards culture reigned, Gartner's assertion that to be a good Canadian was to be a conscious Jew was unique, if not radical. Both this 
assertion and the choir's conscious effort to contribute to the cultural fabric of Canada showed an amazingly courageous insistence that they should be accepted as they were and allowed to influence and mould the nation. Given the post-Holocaust context in which these words were written and the history of anti-Semitic claims that Jews somehow "dirty" other cultures, this insistence is especially poignant.

The choir's insistence that they be included in the fabric of Canada is also remarkable when one considers that they were still very much outside the political mainstream as well. Although the choir's politics were far less radical in the war and postwar years than they had been in the 20s and 30s, they maintained their socialist-oriented left-wing worldview after the war. Perhaps more importantly in terms of public opinion, they remained pro-Soviet until after 1956, when the darker details of Stalin's leadership, especially his murderous attacks on Jewish artists and intellectuals, became public. While their pro-Soviet leanings were considered kosher during the war and the choir enjoyed a high level of popular success throughout the 40 s, as the tensions of the Cold War increased during the 50s, this aspect of their politics became less and less popular with the Canadian mainstream. The dangers of being affiliated with left-wing organizations, rightly or wrongly, was demonstrated in the notorious incident of the "symphony six" who lost their jobs in the Toronto Symphony Orchestra after having trouble traveling to the USA in 1951 (Scher 1992, 29-38). Indeed, the hazards of the blacklist era hit close to home for the choir: during these years their sponsoring organization, the UJPO, was being watched by the RCMP (Scher 1992, 124), and the rehearsals of the choir affiliated with Montreal's UJPO branch were visited by Montreal's so-called Red Squad (Shek, 2004). Eventually the UJPO's Montreal branch was shut down in 1950 under Quebec's anti-red padlock law enforced by Duplessis. In 1951 the UJPO, and with it the choir, were actually excluded from the Canadian Jewish Congress because of their pro-Soviet policies.

It is extraordinary that this organization, marked as outsider both in terms of ethnicity and politics, would hold so tenaciously to a proud nationalistic identity. On the one hand, the disparity between their vision of a pluralistic Canada that included them and the reality of colonial and politically conservative attitudes that existed at the time may make this narrative of nationhood seem a fantasy. On the other hand, the choir's musical activity allowed them to define and inhabit their own imagined community of Canada in a real, embodied way. The choir's history is a testament to the transformative and constitutive power of discourse about music and the performance of music itself, since through musical discourse and in performance the Toronto Jewish Folk Choir was able both to construct a positive Canadian identity for themselves and a Canada that included them. And through their activities they did indeed "contribute to a richer life for us all." 


\section{REFERENCE LIST}

Abella, Irving and Harold Troper. 2000. None is Too Many: Canada and the Jews of Europe 1933-1948. Toronto: Key Porter Books.

Bannerji, Himani. 2000. The Dark Side of the Nation: Essays on Multiculturalism, Nationalism and Gender. Toronto: Canadian Scholars Press.

Biderman, Morris. 2000. My Life on the Jewish Left: An Immigrant's Experience. Toronto: Onward Publishing.

Bissoondath, Neil. 2002. Selling Illusions: The Cult of Multiculturalism in Canada. Toronto: Penguin Books Canada.

Frager, Ruth A. 1992. Sweatshop Strife: Class, Ethnicity and Gender in the Jewish Labour Movement of Toronto. Toronto: University of Toronto Press.

Hall, Stuart. 1996. "Who Needs Identity?" Questions of Cultural Identity, ed. Stuart Hall and Paul du Gay, 1-17. Thousand Oaks: SAGE Publications. Iocovetta, Franca, et al. 1998. A Nation of Immigrants: Women, Workers, and Communities in Canadian History, 1840s-1960s. Toronto: University of Toronto Press.

Jewish Folk Choir Fonds, MUS 43, 1923-76, Library and Archives Canada. Toronto.

Kramer, Lawrence. 2003. "Subjectivity Rampant! Music, Hermeneutics, and History." The Cultural Study of Music: A Critical Introduction. New York: Routledge.

Mackay, Eva. 2002. The House of Difference: Cultural Politics and National Identity in Canada. Toronto: University of Toronto Press.

MacMillan, Ernest. 1955. "Choral Music." Music in Canada, Ernest MacMillan ed. 79-91. Toronto: University of Toronto Press.

Schafer, Paul. 1998. Culture and Politics in Canada: Towards a Culture for All Canadians. Markham: World Culture Project.

Scher, Len. 1992. The Un-Canadians: True Stories of the Blacklist Era. Toronto: Lester Publishing Ltd.

Shek, Ben. 1997. The United Jewish People's Order: A Brief History. Unpublished pamphlet of the United Jewish People's Order. 2004. Conversation with author. 9 June. Toronto, Canada.

Tippet, Maria. 1990. Making Culture: English-Canadian Institutions and the Arts before the Massey Commission. Toronto: University of Toronto Press. Wolters-Fredlund, Benita. 2002. "Leftist, Jewish and Canadian Identities Voiced in the Repertoire of the Toronto Jewish Folk Choir, 1939-59." Canadian Journal for Traditional Music 29: 19-31. 2005. "'We Shall Go Forward with Our Song into the Fight for Better Life': Identity and Musical Meaning in the History of the Toronto Jewish Folk Choir, 1925-1959." Ph.D. dissertation. University of Toronto. 


\section{ABSTRACT}

Using the texts from concert programme notes, this paper describes the growing Canadian identity of Toronto Jewish Folk Choir during and after World War II. During this period the choir used rhetoric similar to what we would today call multiculturalism to argue for their place in Canadian culture. The choir's claims to Canadian identity are juxtaposed with colonialist and assimilationist attitudes toward culture at the time, demonstrating that through musical performance and discourse, the choir members were able to construct a positive Canadian identity for themselves despite their position as an ethnic minority outside the political mainstream.

\section{RESUMÉ}

A partir des notes de programme, cet article décrit l'évolution et la croissance de l'identité canadienne dans la chorale Toronto Jewish Folk Choir, pendant et après la Seconde Guerre mondiale. Durant cette période, la chorale a fait usage d'une rhétorique semblable à celle qu'on qualifierait aujourd'hui de multiculturalisme, afin de justifier leur place dans la culture canadienne. Les prétentions de la chorale à une identité canadienne sont comparées aux attitudes colonialistes et assimilatrices de l'époque envers le domaine culturel. L'exercice démontre, à travers les concerts et les discours, que les membres du chœur étaient en mesure de se construire une identité canadienne positive malgré leur situation de minorité ethnique étrangère au courant politique officiel. 